\title{
Molecular identification of Shiitake [Lentinula edodes Berk (Pegler)] and production of secondary metabolites with biotechnological potential
}

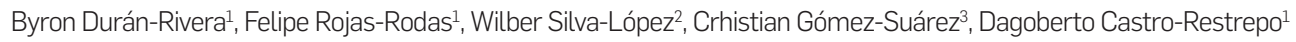

DOI. 10.21931/RB/2020.05.03.3

\begin{abstract}
The Shitake mushroom (Lentinula edodes) is the second most-consumed mushroom in the world; in Colombia, it is cultivated and commercialized on a small scale in some supermarkets. Little is known about the precedence, nutritional and medicinal properties of Shiitake produced in Colombia. In this study, four shiitake isolates were grown in Colombia (LEUCO1, LEUCO2, LEUCO3, and LEUCO4) were sequenced in their ITS genes and evaluated for the production of three medicinal metabolites, eritadenine, ergotioneine and $\beta$-glucans $(1,3-1,6)$, using submerged culture. Genetic analysis revealed that all the isolates were close and related to the Japanese strain Cr62. LEUCO1 and LEUCO2 showed a distance of 0.000, as well as LEUCO3 and LEUCO4. All four isolates produced erythadenin in a range of 26.3-8.6 mg / L, with the best performance of LEUCO1 at $26.3 \mathrm{mg} / \mathrm{L}(\mathrm{p}<0.05)$. Ergotioneine was produced with similar statistical yields in all the isolates with an average of $0.7 \mathrm{mg} / \mathrm{g}$ of dry weight biomass (DW). B-glucans (1.3-1.6) were produced with yields of $5.6-3.8 \%$ of DW biomass, with the best values for LEUCO2 and the lowest for LEUCO4 ( $p<0.05)$. In conclusion, we identified low genetic diversity in the four isolates, corresponding to two haplotypes with minimal genetic difference between them, related to the Japanese strain Cr62, indicating that Colombian farmers cultivate almost the same strains of shitake. Secondary metabolites, eritadenine, $\beta$-glucans and ergotioneine were found in promising yields useful for the pharmaceutical and food industries. More studies should be conducted to improve the yield of shitake metabolites through new growing conditions for industrial production and to find metabolic pathways and related genes.
\end{abstract}

Key words: Eritadenine, ergothioneine, $\beta$-Glucans, ITS genes, Shiitake mushroom.

\section{Introduction}

Gourmet shiitake mushroom has been consumed for more than a thousand years in eastern Asiatic countries and has been studied due to the essential medicinal properties ${ }^{1}$ The mushroom is mainly cultivated in China, Korea, and Japan, and currently is the second more consumed mushroom in the world, after the mushroom (Agaricus spp) with $25 \%$ of total mushroom world production ${ }^{2}$. Most shiitake research has been focused on the medicinal properties, nutritional qualities, and contents of important bioactive substances beneficial to human health. Some known activities are antitumor, immunostimulatory, antibacterial, hypocholesterolemic, and antioxidant $^{3}$. Some of these shiitake substances are proposed to use in pharmaceutical and food industries ${ }^{4}$.

In Colombia, shiitake cultivation initiated in the 80's decade; since then, the mushroom is increasingly becoming more popular in country ${ }^{5}$. Shitake is produced in the Andes under tropical weather conditions that are different from the regions where the mushroom is originated. During the last years, the consumption of Shiitake has increased. The mushroom is sold in supermarkets as a fresh product and is used for food and medicine. However, little is known about the genetic origin of Colombian Shiitake, genetic diversity, and parent strains, as well as the contents of bioactive compounds of shiitakes cultured under the tropical conditions of Colombia. Since the genetic instability has been frequently observed in edible mushrooms $^{6}$, environmental conditions might generate genetic and/or biochemical changes and differences in the secondary metabolite profile ${ }^{7}$. These could influence the potential of Colombian shiitakes usability in biotechnological processes, considering that the mushroom potential to produce secondary metabolites has been already demonstrated ${ }^{8}$

Different studies have been carried out to establish the genetic characterization of shiitake mushrooms in different countries. Xiao et al. ${ }^{9}$ sequenced the whole genome and made a comparison between cultivated and wild strains from China, to evaluate genetic diversity, and George et $a L^{10}$ used ITS sequences in Shiitake to validate identifications of $L$. edodes strains based on morphology characters. ITS sequencing is very accepted in scientific literature to determine identity, genetic diversity, intraspecific variation with high confidence as a universal barcode marker for fungi kingdom, and prokaryotes in general ${ }^{11}$. In the case of shiitake mushroom, molecular identification is essential because there are some other Lentinula species with similar morphological features, as the edible and tropical American native Lentinula boryana ${ }^{12}$. Besides, genetic characteristics are determinant in the production of secondary metabolites ${ }^{13}$.

Obtention of secondary metabolites of Shiitake under submerged culture has become a critical biotechnological process for pharmaceutical and food uses ${ }^{4}$. The purine alkaloid eritadenine [2(R), 3(R)-dihydroxy-4-(9-adenyl] butyric acid), is the primary, secondary metabolite responsible for the hypocholesterolemic action of Shiitake, and has been proposed as pharmaceutical ingredient ${ }^{4}$. HPLC quantitation of eritadenine in carpophores of some shiitake strains has been made by Enman et $a l^{14}$ and Shulei et $a l^{15}$. Additionally, the production of eritadenine by submerged cultivation of shiitake mycelium have described in different studies with unsatisfactory yields ${ }^{16,17}$. Recently, new culture techniques have improved the obtention of this metabolite ${ }^{8}$ 
The secondary metabolite ergothioneine (2-mercaptohistidine trimethylbetaine $=E R G)$ is one of the main antioxidant substances in Shiitake, with potent antioxidant properties for cells and DNA ${ }^{18}$, and is antinflamatory ${ }^{19}$. Different authors evaluated ergothioneine contents in many mushrooms ${ }^{20,21}$. Additionally, other authors showed interest in establishing adequate cultivation parameters, to enhance the ergothioneine production, in Shiitake mycelium ${ }^{22}$ and fruitbodies ${ }^{23}$.

$\beta$-Glucans $(1,3-1,6)$ are anticancer substances conformed by glucose polymer chains, bonded in positions 1-3, and shortly ramified every 3 glucose bonded at 1,6 positions; they contribute significantly to the structure of cell walls in shiitake ${ }^{1}$. Contents of $\beta$-glucanes $(1,3-1,6)$ have been reported by Nitschke et $a^{24}$ in mycelium and carpophores of Shiitake, using a simple spectrophotometric Protocole quantitation with Congo red. Also, Bak et $a l^{1}$ quantitated $a$ and $\beta$ glucans in ten shiitake cultivars in mycelium and fruitbodies, although, the authors do not mention the conditions used to culture the mycelium. Nevertheless, in literature, it was not possible to find comparisons of $\beta$-glucanes $(1,3-1,6)$ yields between different strains of Shiitake, even more under submerged cultivation.

The comparison of yields of eritadenine, ergothioneine and $\beta$-glucanes $(1,3-1,6)$ in various shiitake isolates, could be useful to select strains in biotechnological production of the metabolites. In this study were identified shiitake isolates cultivated in Colombia by sequencing ITS genes and evaluated the production for the secondary metabolites eritadenine, ergotioneine and $\beta$-Glucans $(1,3-1,6)$ under submerged culture.

\section{Methods}

This experiment was carried out at the laboratory of biotechnology, Universidad Católica de Oriente (Rionegro- Colombia), and institute Centro de la Ciencia e Investigación Farmacéutica (CECIF).

\section{Shiitake cultures propagation}

Carpophores of shitake were obtained at different local markets, from four different producers. These were used to obtain axenic cultures by extracting internal tissue with totipotent cells. Mycelium was propagated on malt extract agar (MEA) in Petri dishes and incubated at $24^{\circ} \mathrm{C}$ by twelve days. The isolates obtained were labeled LEUCO1, LEUCO2, LEUCO3, and LEUCO4, and used for genetic characterization and obtention of secondary metabolites.

\section{Genetic characterization of isolates}

Identification of the isolates was carried out according to Sha et all1. DNA was extracted from every insolate using the Invitrogen Purelink Genomic DNA kit. DNA extracted was quantified by light absorption at 260nm (Nanodrop) and visualized in agarose gel. PCR was performed using the primers 5'TCCGTAGGTGAACCTGCGG3' and 5'TCCTCCGCTTATTGATATGC3' for ITS1 e ITS4 respectively. Both primers amplify fragments containing around $600 \mathrm{bp}$. Products of PCR were purified with BSA using the QIAquick PCR purification kit. Thereupon, samples were sequenced by the sanger/capillary method, reading both strands to assure reliability. The sequences were cleaned and ensemble using Cap3 and eBioX 1.5.1 software. Finally, sequences were analyzed through nucleotide $\mathrm{BLAST}^{\circledR}$ to determine the isolates taxonomically. Phylogenetic trees and distance matrixes were performed by using MEGA 6.0 software, neighbor-joining, and maximal verisimilitude with 500 replicates of bootstrap was used.

\section{Fermentations}

Liquid fermentations were set for all the isolates using the broth described by Enman et $a^{16}$. Broths were composed of yeast extract $(2 \mathrm{~g} / \mathrm{L})$, malt extract $(20 \mathrm{~g} / \mathrm{L})$, and glucose (20 $\mathrm{g} / \mathrm{L})$ (Merck, Germany). Fermentations were carried out in 250 $\mathrm{mL}$ Erlenmeyer containing $100 \mathrm{~mL}$ of broth, inoculated with six 0.5 diameter disks of mycelium, from MEA solid cultures. After that, the flasks were incubated in an orbital shaker at $24^{\circ} \mathrm{C}, 120 \mathrm{rpm}$ for 20 days. The biomass obtained was vacuum filtered with number 4 Whatman filter paper, then oven-dried at $40{ }^{\circ} \mathrm{C}$ for two days, and used to quantitate ergothioneine and B-glucans $(1,3-1,6)$ in two separated portions. The fermentation broth was used to quantify the erititadenine.

\section{Eritadenine quantitation}

Eritadenine was quantitated using the HPLC method described by Enman et $a^{16}$. An Agillent Technologies 1200 Series apparatus, equipped with a c18 column, was used. The mobile phase was composed of a gradient of acetonitrile, changing from $2 \%$ to $60 \%$ during the first 10 minutes and $0.1 \%$ trifluoroacetic acid (TFA) from $60 \%$ to $2 \%$, from 10 to 11 minutes (Merck, Germany). The temperature was set at $23^{\circ} \mathrm{C}$, with a detection wavelength at $260 \mathrm{~nm}$. The quantifications were determined using a calibration curve with eritadenine standard, as reference (Santa Cruz Biotechnology Inc.).

\section{Ergothioneine quantitation}

Extraction and quantitation of ergothioneine were done according to Dubost et $a l^{25}$ with few modifications. The dry mycelium was ground to a fine powder with a mortar and pestle, then $\mathrm{MEOH}$ was added in a proportion of $1: 5(\mathrm{w} / \mathrm{v})$, and incubated during $24 \mathrm{~h}$ at room temperature $\left(18^{\circ} \mathrm{C}\right.$ average) in darkness. The mixture was filtered, and the clear methanol extract was used directly for HPLC quantification. Samples were injected through a c18 column (4.6mm x $150 \mathrm{~mm}$, Merck) mounted on an Agilent series 1200 apparatus, at $23^{\circ} \mathrm{C}, 1.0 \mathrm{~mL} / \mathrm{min}$ with a MeCN gradient, starting with $2 \%$ during the first 5 min, changed to $80 \%$ from 5.1 to 10 min, then finally set again to $2 \%$ from 10 to $20 \mathrm{~min}$. Values obtained were compared against a calibration curve constructed with the authentic standard substance (Santa Cruz Biotechnology Inc).

\section{$\beta$-Glucans $(1,3-1,6)$ quantitation}

$\beta$-Glucans were analyzed in all the isolates by three successive extractions in the same sample, according to the procedure of Nitschke et $a^{24}$. Extractions were as follows: 1 ) $\mathrm{KOH}$ fraction was obtained by extracting the pulverized-dried mycelium with $1 \mathrm{M} \mathrm{KOH}$, in a proportion of $40: 1$ (w/v) with stirring, during $20 \mathrm{~min}$ at $60^{\circ} \mathrm{C}$. The extract was cooled down, filtered, neutralized with $6 \mathrm{M} \mathrm{HCl}$ to $\mathrm{pH}=7.0$, and adjusted to $100 \mathrm{ml}$ with distilled water; 2) $\mathrm{HCl}$ fraction was obtained using the filtered cake from the last extract, suspended in $0.55 \mathrm{M}$ $\mathrm{HCl}$, and heated at $100^{\circ} \mathrm{C}$ for $1 \mathrm{~h}$. The extract was filtered and the filtrate neutralized with $6 \mathrm{M} \mathrm{NaOH}$ to $\mathrm{pH}=7.0$ and adjusted to $100 \mathrm{~mL}$ with distilled water; 3) $\mathrm{NaOH}$ fraction, was obtained from filter cake, extracted in $1 \mathrm{M} \mathrm{NaOH}$ at $60^{\circ} \mathrm{C}$ for 20 min, then was cooled down, filtered, neutralized with $6 \mathrm{M} \mathrm{HCl}$ to $\mathrm{pH}=7.0$, and adjusted to $100 \mathrm{~mL}$ with $\mathrm{dH}_{2} \mathrm{O}$.

The quantification of $\beta$-Glucans $(1,3 \rightarrow 1,6)$ was performed using the spectrophotometric method with congo red, developed by Nitschke et $a^{24}$. Into the spectrophotometric (spectroquant Pharo 400, Merck, Germany) cuvette, were put 700 $\mu \mathrm{L}$ of fungal extract, $700 \mu \mathrm{L}$ of Citric acid Buffer (0,2M Citric acid/NaOH, $\mathrm{pH}=7$, Merck, Germany), and $100 \mu \mathrm{L}$ of Congo 
red solution ( $0.08 \mathrm{~g}$ in the citric acid buffer, Merck Germany) Absorbance was read at $553 \mathrm{~nm}$, and the $\beta$-Glucans $(1,3-1,6)$ concentration was determined using a calibration curve constructed with a series of solutions of standard schizophyllan (InvivoGen, USA). $\beta$-Glucans $(1,3-1,6)$ found in the three extracts were added and expressed as total $\beta$-Glucans $(1,3-1,6)$ in $\%$ of the dry weight of mycelium.

\section{Statistics}

Every metabolite was studied by random experimental design with four treatments (isolates) by triplicate, then data were analyzed by ANOVA (Tukey test), or Kruskal-Wallis (Dunn posthoc test) with R studio 4.0.2 of 2020.

\section{Results and discussion}

\section{Genetic characterization}

We could establish the identity of four shiitake mushrooms of unknown origin cultivated in Colombia by sequencing two ITS genes. PCR products from the isolates were purified, visualized with electrophoresis and sequenced for ITS1 and ITS4 genes (Figure 1a). The sequences obtained were $649 \mathrm{bp}$ long in all four isolates, identified as Lentinula edodes species, and were compared with the elite strain Cr62 from genebank (https://www.ncbi.nlm.nih.gov/genbank/). Genetic distance values were generated along with a Neighbor-Joining phylogenetic tree (Figure 1, B and C).

ITS sequences revealed profound differences between isolates (matrix fig. $1 \mathrm{~B}$ ). The sequences were gathered in two homolog groups (haplotypes) 1) LEUCO1-LEUCO2 and 2) LEUCO3-LEUCO4, with 0.000 distance in between, close to the elite strain Cr62. Distances between Cr62 and the isolates were equally low. The first group had a difference of $0.15 \%$ with the strain Cr62, with one base substitution and one deletion. The second had a difference of $1.57 \%$, nine bases substitution in a different order, and two deletions. Contradictorily, Sha et a ${ }^{111}$, found a variation of up to 138 bases in wild samples of the gourmet mushroom Thelephora ganbajun from china. These resulting distances confirm a low genetic diversity in the evaluated isolates. Additionally, Nilsson et $a^{26}$ found from an exhaustive reviewing of sequences covering the fungi kingdom, an average intraspecific variability of $2.51 \%$ based on ITS sequences. Accordingly, Xiao et $a l^{9}$ found a reduced genetic diversity in Chinese shiitake cultivars compared to wild strains, probably caused by human selection and breeding.

\section{Eritadenine assay}

All four isolates produced eritadenine (8.6 - $26.3 \mathrm{mg} / \mathrm{L})$. Best yields were attained by LEUCO1 $(26.3 \mathrm{mg} / \mathrm{L})$, with statistical differences with the rest of isolates (Table 1). Here, yields were higher than those published by other authors ${ }^{16,17}$ with maximal yields of 8.6 and $25 \mathrm{mg} / \mathrm{L}$, using broths of complex nutritional composition, and lower than $88 \mathrm{mg} / \mathrm{L}$ obtained in other experiments with alginate inmobilization ${ }^{8}$.

Few reports exist in the literature related to the obtention of eritadenine by different shiitake strains in submerged culture. Enman et $a l^{14}$, found in carpophores of four shitake strains maximal yield of $6.33 \mathrm{mg} / \mathrm{g}$, with no significant statistical differences, also Shulei et a ${ }^{15}$ reported $1.99 \mathrm{mg} / \mathrm{g}$ in carpophores, without mentioning the strain. Both authors did not report the

\begin{tabular}{|c|c|c|c|c|c|}
\hline Isolate & $\begin{array}{c}\text { Eritadenine } \\
\mathrm{mg} / \mathrm{L}\end{array}$ & $\begin{array}{c}\text { Total } \beta \text {-glucanes 1,3-1,6 } \\
\text { DW \% }\end{array}$ & $\begin{array}{c}\text { Ergothioneine } \\
\text { mg/g DW }\end{array}$ & pHf & Biomass $\mathrm{g} / \mathrm{L}$ \\
\hline LEUCO1 & $26.3 \pm 1.4 \quad a$ & $4.78 \pm 0.4 \mathrm{ab}$ & $0.73 \pm 0.04 a$ & $3.28 \pm 0.03 \mathrm{a}$ & $1.21 \pm 0.04 \mathrm{a}$ \\
\hline LEUCO2 & $13.2 \pm 1.3 \quad \mathrm{~b}$ & $5.61 \pm 0.8 \mathrm{a}$ & $0.72 \pm 0.08 \mathrm{a}$ & $3.40 \pm 0.2 \quad a$ & $1.82 \pm 0.06 \mathrm{ab}$ \\
\hline LEUCO3 & $13.3 \pm 0.1 b$ & $4.33 \pm 0.4 b c$ & $0.62 \pm 0.2 \quad a$ & $3.43 \pm 0.2 \quad a$ & $1.92 \pm 0.07 \mathrm{~b}$ \\
\hline LEUCO4 & $8.6 \pm 0.1$ & $3.81 \pm 0.2 \mathrm{c}$ & $0.76 \pm 0.06 \mathrm{a}$ & $3.52 \pm 0.2 \mathrm{a}$ & $1.89 \pm 0.07 \mathrm{~b}$ \\
\hline
\end{tabular}

Table 1. Yields of metabolites on average after 20 days of submerged fermentation with shiitake mycelium.

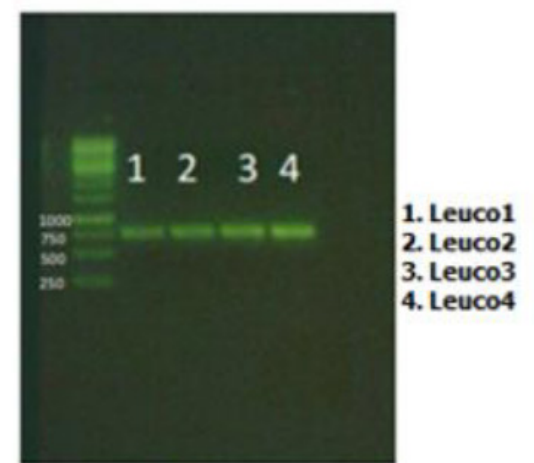

A

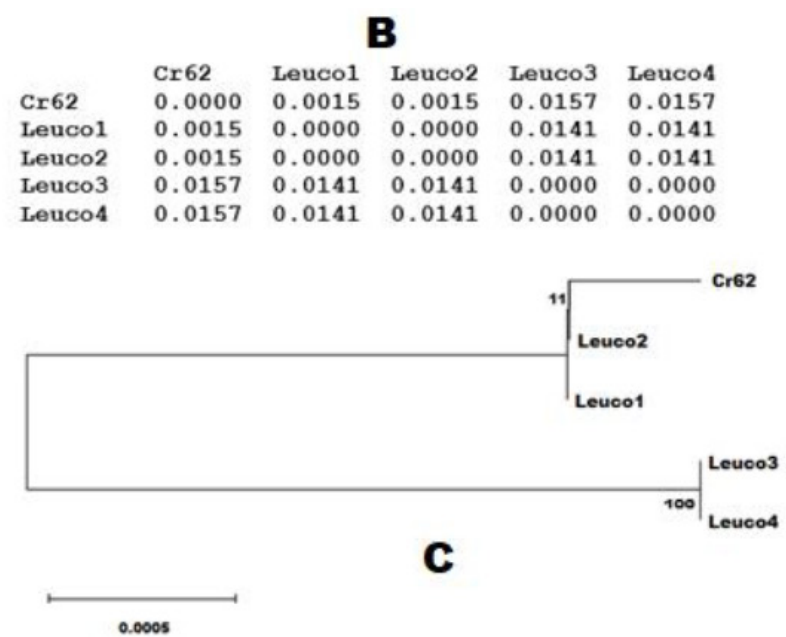

Figure 1. Genetic characterization to the isolates. A: purified products of PCR; B: Distances matrix between the isolates, and C: Phylogenetic tree for all four isolates together with Cr62 elite shiitake strain. 
methods used to produce the carpophores, then possibly, the differences were not only due to genetic differences but also to cultivation conditions, as samples were obtained from different producers. The latter probably used different environmental and nutritional conditions.

Here we have three groups of shiitake isolates (LEUCO1, LEUCO4, and LEUCO2-LEUCO3) that express eritadenine genes at different levels. Seemingly those differences in eritadenine expression do not have a clear relationship with the distances obtained (Fig 1), which could be a logical assumption as ITS genes do not encode for enzymes, then do not participate in eritadenine biosynthesis pathway. Accordingly, Schwessinger et $a^{27}$ found gen expression variation of $6 \%$ in Puccinia striiformis, which occur in dikaryotic isolates (diploids) with sexual reproduction, as the Shiitake isolates evaluated in the present research. Also, the production of purine precursors to eritadenine (AICAR and SAICAR) from the inosine monophosphate (IMP) pathway, are expressed in different levels by different strains of yeast Saccharomyces cereviciae, and those genes are activated in yeast by adding adenine to the nutritional medium $^{28}$. As eritadenine pathway is not understood ${ }^{17}$, future research studies should be directed to identify genes related to eritadenine biosynthesis ${ }^{27}$.

\section{$\beta$-glucans $(1,3-1,6)$}

All four isolates produced $\beta$-glucans in a range from $3,8 \%$ to $5,6 \%$ of DW of mycelium. LEUCO2 produced the higher yields, without statistical differences with LEUCO1. On the other hand, LEUCO4 produced the lowest yields, without statistical differences with LEUCO3 (Table 1). LEUCO2 produced slightly more than twice $\beta$-glucans $(1,3-1,6)$ the yields reported by Nitschke et $\mathrm{al}^{24}$. This author obtained 2,58 g/100 in shiitake mycelium, using the same extraction and quantitation protocols than this experiment. Nonetheless, the strain name was not reported, and the cultivation conditions were broths of yeast and malt extracts, at $80 \mathrm{rpm}$ (different than used in this experiment).

Likewise, other studies reported differences in $\beta$-glucans contents in different cultivars of shiitake mushroom ${ }^{1}$ and in Agaricus subrufescens ${ }^{29}$. These differences in $\beta$-glucans $(1,3-1,6)$ yields were probably due to the homeostasis between $\beta$ - $(1,3)$-glucan synthase, the primary enzyme responsible for fungal cell wall construction ${ }^{30}$. And the $\beta$-glucans destructive counterparts $\beta$ - $(1,3)$-glucanases ${ }^{31}$. In Shiitake, various glucanases coding genes have been identified, which are upregulated in postharvest shiitake fruiting, leading to the autolysis of cell wall ${ }^{32,33}$.

In Lentinula edodes composition of the cell wall is well known, mainly consisting of polysaccharides like chitin and $\beta$-glucanes ${ }^{2}$. Those are synthesized by the enzyme $\beta$ - $(1,3)$-glucan synthases that have a catalytic subunit FKS, plus a regulatory one RHO, both encoded by FKS and RHO genes ${ }^{34}$. However, there is inadequate knowledge about the transcriptional regulation of this enzymatic biosinthesis ${ }^{34}$. We hypothesize that nutrition and environmental conditions used in this experiment, especially the glucose concentration of the broth, produced a positive balance in favor of $\beta$-(1,3)-glucan synthase activity in LEUCO2 (the more productive isolate), but not for LEUCO4.

\section{Ergothioneine assay}

All isolates produced similar ergothioneine yields, ranging from 0,62 to $0,75 \mathrm{mg} / \mathrm{g}$ DW of mycelium, with an average of $0.7 \mathrm{mg} / \mathrm{g}$, to all the isolates. These concentrations did not show significant statistical differences between isolates but were higher than the concentrations reported by Tepwong et $a^{22}$, who found $0.5 \mathrm{mg} / \mathrm{g}$ for Shiitake mycelium pellets in submerged culture. And seventeen times higher than the yields reported by Jang et a ${ }^{23}$ who used Shiitake submerged cultures supplemented with various nitrogen sources. Unexpectedly, the isolates used in this experiment contained eight times more ergothioneine than the body fruiting of the popular Ganoderma lucidum ${ }^{21}$.

Few reports in literature compare ergothioneine content in different strains of edible mushrooms related to Shiitake. Contrary to this research, Chen et $a^{20}$ found different ergothioneine concentrations in the mycelium of three strains of Cordyceps militaris, and in three commercial carpophores of Pleurotus ostreatus from China, Korea, and Japan. However, the authors do not report cultivation methods to obtain carpophores or mycelium; then, it is possible to speculate that differences are related to the possible different cultivation conditions. Hence, to obtain accurate comparisons, fungal cultures for chemotaxonomic analysis should be grown in the same medium and incubation conditions, to ensure that differences correspond to fungal genetic diversity and not to environmental conditions ${ }^{35}$.

Nitrogen source is critical for ergothioneine biosynthesis, amino acids like cysteine, methionine, and histidine are precursors of the substance ${ }^{36}$. By adding methionine to liquid broths, ergothioneine yields are increased up to twice, compared to fermentation without the addition of aminoacids ${ }^{37}$. This is due to histidine is a precursor of ergothioneine ${ }^{22,37}$. Then the low ergothioneine yields obtained in this experiment were probably due to the lack of precursor amino acids in the yeast extract used. For instance, Lin et $a l^{38}$ found in submerged cultures of Pleurotus citrinopileatus a higher ergothioneine yield $10.65 \mathrm{mg} / \mathrm{g}$, by using tryptone instead of yeast extract. Probably tryptone contains 1.6\% of methionine, while yeast extracts only $0.8 \%$. In this sense, we hypothesized that the use of nitrogen sources rich in the amino acids mentioned above might improve ergothioneine yields produced in the shiitake isolates of this experiment.

\section{Biomass production and final $\mathrm{pH}$ obtained in fermentations}

All four isolates produced biomass after twenty days of fermentation in a range from 1.21 to $1.92 \mathrm{~g} / \mathrm{L}$. LEUCO2, LEU$\mathrm{CO} 3$, and LEUCO4 produced the higher biomass (1.82, 1.92, and $1.89 \mathrm{~g} / \mathrm{L}$ respectively) without significant statistical differences between them. At the same time, LEUCO1 produced the lowest value $(1.21 \mathrm{~g} / \mathrm{L})$, statistically similar to LEUCO2. Accordingly, shiitake strains show different utilization of nutritional components in liquid broths, which affects biomass yields. This was demonstrated by López-Peña et $a^{39}$, who found two high biomass producing strains $3.73 \mathrm{~g} / \mathrm{L}$ and $8.79 \mathrm{~g} / \mathrm{L}$, from six evaluated. In this sense, the differences between the isolates could be attributed to incubation temperature $\left(24^{\circ} \mathrm{C}\right)$. Probably this temperature was not optimal for the isolate LEUCO1 and LEUCO2. According to Lee et $a l^{40}$, every strain has an optimum growth temperature. For instance, Quaicoe et $a l^{41}$ found different radial growth in three shiitake strains at $20^{\circ} \mathrm{C}$, cultured in potato dextrose agar (PDA).

On the other hand, final $\mathrm{pH}$ had statistically similar values in fermentations of all isolates, ranging from 3.28 to 3.52. Different authors found similar $\mathrm{pH}$ at the end of fermentations, Enman et $a^{17}$, obtained a final $\mathrm{pH}$ of 3.5-3.6 for Shiitake under submerged culture, with eritadenine yields of $25 \mathrm{mg} / \mathrm{L}$. The same authors established that optimal $\mathrm{pH}$ for eritadenine production could be in a range from 3 to 4. Likewise, Quaiqoe et 
$a l^{41}$ established a $\mathrm{pH}$ range from 3 to 4 as optimal for shiitake mycelium growth at in vitro culture. According to the above authors, our four shiitake isolates of this experiment reduced the $\mathrm{pH}$ to the expected values of optimal growth. Nonetheless, there is not enough evidence about the effect of $\mathrm{pH}$ on eritadenine, ergothioneine, and $\beta$-glucans yields. Even more, for eritadenine production with Shiitake, variables that produce good biomass growth are not necessarily the same to produce high metabolite yields ${ }^{17}$.

Finally, after 20 days of fermentation, all isolates produced biomass in the form of well-defined pellets. The 120-rpm agitation promotes this growth morphology. Similarly, other studies obtained pellets of shiitake mycelium under submerged culture, at the same agitation values $[42,37]$. Growth morphology insides on metabolites production, shiitake pellets produce higher yields of ergothioneine compared to cultures with no pellets formation.

\section{Conclusions}

In this investigation, we identified low genetic diversity in the four shiitake isolates examined, which correspond to the fungi most commonly produced in Colombia. These findings allow us to conclude that the four isolates formed two haplotypes LEUCO1-LEUCO2 and LEUCO3-LEUCO4 with little genetic difference between them, but related to the elite Japanese strain Cr62. All strains produced the pharmaceutical metabolites eritadenine in a promising concentration for industrial use: $\beta$-glucans (1-3, 1-6) and ergothioneine. LEUCO1 was more suitable for the production of eritadenine, while LEUCO1, 2, and 3 were more suitable for producing $\beta$-glucans. Furthermore, all four isolates produced the same amounts of ergotioneine. Finally, biomass was better produced by LEUCO2, 3 and 4. Further research could be aimed at improving shiitake metabolite yields and optimizing culture and incubation systems, for industrial production, and finding metabolic pathways and genes related.

\section{Acknowledgements}

Authors want to be thankful to investigación \& Desarrollo at Universidad Catolica de Oiriente, to CECIF (Centro de la ciencia y la investigación farmacéutica). Both institutions suported entusiastically the research, and to Dr. Carlos Eduardo Giraldo Sánchez who colaborated us with the genes sequences analysis.

\section{Bibliographic references}

1. Bak WC, Park JH, Park YA, Ka KH (2014) Determination of Glucan Contents in the Fruiting Bodies and Mycelia of Lentinula edodes Cultivars. Mycobiology 42(3): 301-304. doi: 10.5941/ MYC0.2014.42.3.301

2. Jiang T, Wang Q, Xu S, Jahangir MM, Ying T (2010) Structure and composition changes in the cell wall in relation to texture of shiitake mushrooms (Lentinula edodes) stored in modified atmosphere packaging. J Sci Food Agric. 90:742-749. https://doi.org/10.1002/jsfa.3876

3. Bisen PS, Baghel RK, Sanodiya BS, Thakur GS, Prasad GBKS (2010) Lentinus edodes: A Macrofungus with Pharmacological Activities. Curr Med Chem. 17: 2419-2430. https://www.ncbi.nlm. nih.gov/pubmed/20491636

4. Enman J, Patra A, Ramser K, Rova U, Berglund KA (2011) Solid State Characterization of Sodium Eritadenate. Am. J. Anal. Chem 2:164-173. DOI: 10.4236/ajac.2011.22019

5. Romero-Arenas O, Martínez GM, Damián MA, Ramírez B, López-Olguín F (2015) Producción del hongo Shiitake (Lentinula edodes Pegler) en bloques sintéticos utilizando residuos agroforestales. Rev. Mex. Cienc. Agríc 6(6): 1229-1238. http://www.scielo.org.mx/pdf/remexca/v6n6/v6n6a7.pdf
6. Mallick P, Sikdar SR (2015) Genome instability in fruit body derived lines generated from fruiting pfle somatic hybrid lines and development of hybrid strain specific scar marker in edible mushroom. J. Hort. Res 23(2): 111-120. DOI: 10.2478/johr-2015-0022

7. Torres S, cabrera-pardo J, Alonso f, Bustos E, Pérez C, Palfner G, Hernández V, Uriarte E, Becerra J (2016) Changes in secondary metabolites profiles and biological activity of the fresh fruiting bodies of stereum hirsutum exposed to high-dose uv-b radiation. J. Chil. Chem. Soc 61(4): 3224-3227. http://dx.doi.org/10.4067/ S0717-97072016000400015

8. Duran-Rivera B, Moreno-Suarez J, Rojas RF, Valencia KM, Castro-Restrepo $D$ (2018) Enhancement of eritadenine production using three carbon sources, immobilization and surfactants in submerged culture with shiitake mushroom (Lentinula edodes) (Berk.) Singer). Afr. J. Food Sci 12(12): 374-382. DOI: 10.5897/AJFS2017.1654

9. Xiao Y, Cheng X, Liu J, Li C, Nong W, Bian Y, Kit MC, Shan HK (2016) Population genomic analysis uncovers environmental stressdriven selection and adaptation of Lentinula edodes population in China. Sci. Rep. 6(36789):1-12. https://doi.org/10.1038/srep36789

10. George PL, Sripathi VR, Nyaku ST, Sharma GC, Kantety RV (2016) DNA-based identification of Lentinula edodes strains with species-specific primers. Afr. J. Biotechnol 15(7):191-198. DOI: 10.5897/AJB2015.15089

11. Sha T, Xu J, Palanichamy GM, Zhang H-B, Li T, Zhao Z-W, Zhang Y-P (2008) Genetic diversity of the endemic gourmet mushroom Thelephora ganbajun from southwestern China. Microbiology 154: 3460-3468. DOl: 10.1099/mic.0.2008/020495-0

12. Gaitán-Hernández R, Salmones D (2015) Uso de residuos lignocelulósicos para optimizar la producción de inóculo y la formación de carpóforos del hongo comestible Lentinula boryana. Rev. Mex. Cienc. Agríc 6(7):1639-1652. DOl: 10.29312/remexca.v6i7.556

13. Pandit SS, Lohmar JM, Ahmed S, Etxebeste O, Espeso EA, Calvo AM (2018) UrdA Controls Secondary Metabolite Production and the Balance between Asexual and Sexual Development in Aspergillus nidulans. Genes 9(570): 1-23. DOI: 10.3390/genes9120570

14. Enman J, Rova U, Berglund K (2007) Quantification of the Bioactive Compound Eritadenine in Selected Strains of Shiitake Mushroom (Lentinus edodes). J Agric Food Chem 55: 1177-1180. DOl:10.1021/jf062559+

15. Shulei W, Jingyu L, Qingjiu T, Yangfang L, Shuai Z, Yan Y, Jingsong Z (2011) Determination of Eritadenine in Lentinula edodes Fruit bodies Using HPLC. Acta edulis fungi 18(2): 52-56. http://en.cnki.com.cn/ Article_en/CJFDTOTAL-SYJB201102014.htm

16. Enman J, Hodge D, Berglund KA, Rova U (2008) Production of the Bioactive compound Eritadenine by Submerged Cultivation of Shiitake (Lentinus edodes) Mycelia. J Agric Food Chem 56: 2609-2612. DOl:10.1021/jf800091a

17. Enman J, Hodge D, Berglund KA, Rova U (2012) Growth promotive conditions for enhanced eritadenine production during submerged cultivation of Lentinus edodes. J. Chem. Technol. Biotechnol 87(7): 903-907. https://doi.org/10.1002/jctb.3697

18. Csoyan K, Numan BM, Baspinar N, Taspinar M, Aydos S (2012) Ergothioneine attenuates the DNA damage of post-thawed Merino ram sperm. Small Ruminant Res 106:165-167. https://doi.org/10.1016/j. smallrumres.2012.02.002

19. Laurenza I, Colognato R, Migliore L, Del Prato S, Benzi L (2008) Modulation of palmitic acid-induced cell death by ergothioneine: evidence of an anti-inflammatory action. Biofactors 33:237-47. https:// doi.org/10.1002/biof.5520330401

20. Chen SY, Ho KJ, Hsieh YJ, Wang LT, Mau JL (2012) Contents of lovastatin, g-aminobutyric acid and ergothioneine in mushroom fruiting bodies and mycelia. LWT-Food Sci Technol 47: 274-278. https:// doi.org/10.1016/j.lwt.2012.01.019

21. Lee WY, Park E-J, Ahn JK, Ka K-J (2009) Ergothioneine Contents in Fruiting Bodies and Their Enhancement in Mycelial Cultures by the Addition of Methionine. Mycobiology 37(1): 43-47. doi: 10.4489/ MYCO.2009.37.1.043

22. Tepwong P, Giri A, Sasaki F, Fukui R, Ohshima T (2012a) Mycobial enhancement of ergothioneine by submerged cultivation of edible mushroom mycelia and its application as an antioxidative compound. Food Chem 131: 247-258. https://doi.org/10.1016/j.foodchem.2011.08.070 
23. Jang Y, Park J, Ryoo R, Park Y, Ka K-H (2016) Ergothioneine Contents of Shiitake (Lentinula edodes) Fruiting Bodies on Sawdust Media with Different Nitrogen Sources. Kor. J. Mycol 44(2): 100-102. DOl: http://dx.doi.org/10.4489/KJM.2016.44.2.100

24. Nitschke J, Modick H, Busch E, von Rekowski RW, Altenbach H-J, Mölleken H (2011) A new colorimetric method to quantify b-1,3-1,6glucans in comparison with total b-1,3-glucans in edible mushrooms b-1,3-glucans in edible mushrooms. Food Chem 127:791-796. DOl: 10.1016/j.foodchem.2010.12.149

25. Dubost NJ, Beelman RB, Royse DJ (2007) Influence of selected cultural factors and postharvest storage on ergothioneine content of common button mushroom Agaricus bisporus (J. Lge) Imbach (Agaricomycetideae). Int. J. Med. Mushrooms 9:163-176. DOI 10.1615/IntJMedMushr.v9.i2.70

26. Nilsson RH, Kristiansson E, Ryberg M, Hallenberg N, Larsson KH (2008) Intraspecific ITS Variability in the Kingdom Fungi as Expressed in the International Sequence Databases and Its Implications for Molecular Species Identification. Evol Bioinform 4:193-201. https://www.ncbi.nlm.nih.gov/pmc/articles/PMC2614188/

27. Schwessinger B, Sperschneider J, Cuddy W, Garnica D, Miller M, Taylor J, Dodds P, Figueroa M, Parck R, Rathjen J (2018) A Near Complete Haplotype-Phased Genome Of The Dikariotic Wheat Stripe Rust Fungus Puccinia striiformis f. sp. tritici Reveals High Interhaplotype Diversity. Mbio 9(1): e02275-17. DOI: 10.1128/mBio.02275-17

28. Rebora K, Laloo B, Daignan-Fornier B (2006) Revisiting Purine-Histidine Cross-Pathway Regulation in Saccharomyces cerevisiae: A Central Role for a Small Molecule. Genetics 170: 61-70. DOl:10.1534/ genetics.104.039396

29. Clemente TRC, Andrade CM, Oliveira LLC, Barros V-BV, de Souza DE (2013) Measurement of B-glucan and other nutritional characteristics in distinct strains of Agaricus subrufescens mushrooms. African journal of Biotechnology. 12(43): 6203-6209. http://dx.doi. org/10.5897/AJB2013.13024

30. Orlean P (2012) Architecture and Biosynthesis of the Saccharomyces cerevisiae Cell Wall. Genetics 192(3): 775-818. DOI: 10.1534/ genetics.112.144485

31. Bauermeister A, Giese E-C, Borsato D, Rezende M-I, Dekker F-H, Barbosa A-M (2017) Filamentous Fungal Biomass as Inducer of Extracellular B-1,3-Glucanases and B-Glucosidases by Aureobasidium Pullulans 1WA1". ECMi 5(4): 138-147. https://www.ecronicon.com/ ecmi/pdf/ECMI-05-0000142.pdf

32. Sakamoto Y, Nakade K, Sato S, Yoshida K, Miyazaki K, Natsume S, Konno N (2017) Lentinula edodes Genome Survey and Postharvest Transcriptome Analysis. Appl Environ Microbiol 83(10): e02990-16. DOI: 10.1128/AEM.02990-16

33. Konno N, Nakade K, Nishitani Y, Mizuno M, Sakamot Y (2014) Lentinan Degradation in the Lentinula edodes Fruiting Body during Postharvest Preservation Is Reduced by Downregulation of the exoß-1,3-Glucanase EXG2. J Agric Food Chem 62: 8153-8157. DOI: dx.doi.org/10.1021/j5501578w.
34. Chai R, Qiu C, Liu D, Qi Y, Gao Y, et al (2013) $\beta$-Glucan Synthase Gene Overexpression and $\beta$-Glucans Overproduction in Pleurotus ostreatus Using Promoter Swapping. PLoS ONE 8(4): e61693. https://doi. org/10.1371/journal.pone.0061693

35. Frisvad JC, Andersen B, Thrane U (2008) The use of secondary metabolite profiling in chemotaxonomy of filamentous fungi. Mycol Res. 112: 231-240. DOl:10.1016/j.mycres.2007.08.018

36. Pluskal T, Ueno M, Yanagida M (2014) Genetic and Metabolomic Dissection of the Ergothioneine and Selenoneine Biosynthetic Pathway in the Fission Yeast, S. pombe, and construction of an Overproduction System. PLOS ONE 9(5): 1-12. DOI: 10.1371/journal.pone.0097774

37. Tepwong P, Giri A, Ohshima T (2012b). Effect of mycelial morphology on ergothioneine production during liquid fermentation of Lentinula edodes. Mycoscience 53:102-112. https://doi.org/10.1007/S10267011-0145-0

38. Lin S-Y, Chien S-C, Wang S-Y, Mau J-L (2015) Submerged Cultivation of Mycelium with High Ergothioneine Content from the Culinary- medicinal Golden Oyster Mushroom, Pleurotus citrinopileatus (Higher Basidiomycetes). Int J Med Mushrooms 17(8): 749-761. DOI: 10.1615/IntJMedMushrooms.v17.i8.50

39. López-Peña D, Gutiérrez A, Esqueda M (2013) Cinética de crecimiento y composición química del micelio de Lentinula edodes cultivado en medio líquido suplementado con extractos de madera de vid. Rev. Mex. Mic 37: 51-59. http://www.scielo.org.mx/pdf/ $\mathrm{rmm} / \mathrm{v} 37 / \mathrm{v} 37 \mathrm{a} 7 . \mathrm{pdf}$

40. Lee S, Bae H, Kim N, Hwang S (2008) Optimization of Growth Conditions of Lentinus edodes Mycelium on Corn Processing Waste Using Response Surface Analysis. J Biosci Bioeng 105(2): 161-163. DOl: 10.1263/jbb.105.161

41. Quaicoe EH, Amoah C, Obodai M, Odamtten GT (2014) Nutrient requirements and environmental conditions for the cultivation of the medicinal mushroom (Lentinula Edodes) (Berk.) in Ghana. IJSTR 3(12): 45-50. http://www.ijstr.org/final-print/ dec2014/Nutrient-Requirements-And-Environmental-Conditions-For-The-Cultivation-Of-The-Medicinal-Mushroom-lentinula-Edodes-berk-In-Ghana.pdf

42. Ting LTC, Tsao HH, Wang AY, Chang CA (2007) Pressurized Water Extraction of Polysaccharides as Secondary Metabolites from Lentinula edodes. J Agric Food Chem 55: 4196-4201. DOI: 10.1021/ jf070035j

Received: 7 July 2020

Accepted: 7 agost 2020 